Has this any application to university education-and particularly to training for public service?

\title{
DECISIONS OF STATE COURTS ON POINTS OF PUBLIC LAW
}

Separation of Powers. Ormsby County vs. Kearney. (Nevada, August 4, 1914. 142 Pac. 803.) Sustains the statute vesting the determination of water rights in the state engineer, subject to an appeal to the courts. Full opinion discussing constitutional aspects, also dissenting opinion.

Delegation of Legislative Power. State vs. Howard. (Nebraska, May 29, 1914. 147 N.W. 689.) An act of 1913 directs the insurance board to prepare a form of fire insurance policy as nearly as practicable in the form known as the New York standard. Other provisions of the act have however the effect of varying some of the provisions of the New York standard form.

The duty of the board is to arrange and prepare in proper form the form of contract required under the Nebraska statute, omitting all provisions of the New York form which are in conflict with the law of $\mathrm{Ne}$ braska. Its duties are therefore administrative and not legislative and there is no unconstitutional delegation of legislative power.

The direction to use the New York form, as it may hereafter be constituted is, however, invalid because the duties of the officials of the State would thereby be controlled by the future action of the legislature of another State.

Home Rule. Davis vs. Holland. (Texas, May 30, 1914. 168 S.W. 11.) A charter provision giving a city the exclusive right to control draining and plumbing, cannot prevail against a general state law upon the same subject, since under the constitution authority cannot be conferred upon the city to suspend state laws.

Civil Rights and Police Power. Streich vs. Board of Education. (South Dakota, June 8, 1914.147 N.W. 779.) In the absence of a legislative prohibition a school district may by resolution require of pupils seeking admission into the public schools the furnishing of a physical record card. This is a reasonable exercise of the police power which does not illegally add to or vary the statutory qualifications for enjoying the benefits of the public school system of the State. "The report asked for would lead to the exclusion of the pupil only when it showed that the child was not of school age, that it was not a resident of the district, or, if the 
respondents so ordered, when it showed that the child was then suffering from some disease rendering it a menace to its associates."

Personal rights-regulation of marriage. Peterson vs. Widule. (Wisconsin, June 17, 1914. 147 N.W. 966.) Wisconsin eugenics law sustained. The State may require of applicants for license to marry the submission to recognized tests to ascertain freedom from disease. Such requirement may be confined to males.

Police power-articles of consumption. State vs. Hutchinson Ice Cream Company. (Iowa, May 12, 1914. 147 N.W. 195.) The standardizing of ice cream by fixing permissible ingredients is within the police power of the State, although the object of the law is not sanitary, but merely to prevent fraud.

Police power-regulation of business. State vs. Pitney. (Washington, May 16, 1914. 140 Pac. 918.) The State may, by imposing an annual license fee of $\$ 6000$, in effect prohibit the use of trading stamps in the sale of goods.

"This conclusion, it must be admitted, is not in harmony with the great weight of authority, numerically speaking. But many, if not most, of the decisions that have held trading stamp laws inimical to the due process of law clause found in the constitutions, were decided when the police power was defined as having a more limited scope than it has at the present time."

Police power-licenses. Keller vs. State. (Maryland, February 25 and May 13, 1914. 90 Atl. 603.) The State may validly require as a condition for engaging in the business of an undertaker the possession of a license to be issued by a board upon examination.

Police power-outdoor advertising. Horton vs. Old Colony Bill Posting Company. (Rhode Island, June 26, 1914. 90 Atl. 822.) An ordinance regulating structures for advertising sustained as a safety measure. The police board may be vested with power to refuse the written approval required for out-door advertising if it decides that the matter to be displayed is immoral.

Police power-retroactive regulation. (Re McIntosh. 211 N.Y. 265. 105 N.E. 414.) A city ordinance may forbid the issue of garage per- 
mits for buildings situated within 50 feet of a school or tenement house or place of public amusement or assembly, and the prohibition may be applied to buildings used as garages at the time of the enactment of the ordinance, and not available for any other kind of business.

Municipal regulation of business. Brittingham etc. Company vs. Sparta. (Wisconsin, May 21, 1914. 147 N.W. 635.) A city ordinance may require all coal sold in the city to be weighed on city scales. This is not an illegal discrimination against coal dealers. The court, however, holds that the dealer cannot be punished for not complying with the ordinances if ample opportunities for weighing are not afforded by the city.

Equality-franchise grants. East Boyer Telephone Company vs. Inc. Town of Vail. (Iowa, May 16, 1914. 147 N.W. 327.) The use of streets for a quasi public purpose being a special privilege, it does not violate the equal protection of the laws, that the right is conditioned upon the consent of the voters, whereby the use of the streets may be granted to one telephone company and denied to another.

Objects of taxation-public relief. State vs. Edmondson. (Ohio, February 3, 1914. 106 N.E. 41.) An act providing relief for any person (satisfying specified requirements of residence) who, by reason of loss of eyesight, is unable to provide himself with the necessaries of life and has not sufficient means of his own to do so, is unconstitutional as a mere bounty, since the person declared entitled to relief may be actually supported by children and friends. Otherwise where the relief is confined to one who unless thus relieved would become a charge upon the public or upon those not required by law to support him.

Taxation-special assessment. Shultise vs. Taloga. (Oklahoma, May 12, 1914. 140 Pac. 1190.) The apportionment of the entire cost of a sidewalk pavement upon the abutting lots according to their frontage without any preliminary hearing as to benefits, may be authorized by the legislature, and this will not constitute a taking of property without due process of law.

Due process-punishment. Strong vs. State. (Tennessee, May 9, 1914. $166 \mathrm{~S}$. W. 967.) An act is unconstitutional which provides that a prisoner who escapes and is recaptured may be held without hearing to work out the costs of the recapture. 
Due process-enforcement in equity: "red light injunction." State vs. Fanning. (Nebraska, May 4, 1914. 147 N.W. 215). State vs. Gilbert. (Minnesota, June 12, 1914. 147 N.W. 953.) Acts sustained which permit proceedings in equity in the name of the state to abate as a nuisance a building used as a disorderly house.

The Nebraska case holds the provision assessing a penalty or tax on the building to be unconstitutional, but sustains the provision for closing the house for one year unless sooner released on bond.

The Minnesota case holds both provisions to be valid, the assessment being treated as a tax (relying on 121 Iowa 482.196 U.S. 279.) 